Article

\title{
Citizens' Behavior as a Driver of Energy Transition and Greening of the Economy in the Russian Arctic: Findings of a Sociological Survey in the Murmansk Region and Karelia
}

\author{
Sergey Tishkov $^{1, *(\mathbb{D})}$, Arsen Tleppayev ${ }^{2} \mathbb{D}$, Valentina Karginova-Gubinova ${ }^{1} \mathbb{D}$, Alexander Volkov ${ }^{1} \mathbb{D}$ \\ and Anton Shcherbak ${ }^{1}$ (D) \\ 1 Institute of Economics, Karelian Research Centre, RAS, 185910 Petrozavodsk, Russia; \\ vkarginowa@yandex.ru (V.K.-G.); kov8vol@gmail.com (A.V.); scherbaka@mail.ru (A.S.) \\ 2 Faculty of Economic Sciences, Kazakh-German University, Almaty 050010, Kazakhstan; arsentlp@gmail.com \\ * Correspondence: insteco_85@mail.ru
}

Citation: Tishkov, S.; Tleppayev, A.; Karginova-Gubinova, V.; Volkov, A.; Shcherbak, A. Citizens' Behavior as a Driver of Energy Transition and Greening of the Economy in the Russian Arctic: Findings of a Sociological Survey in the Murmansk Region and Karelia. Appl. Sci. 2022, 12, 1460. https://doi.org/10.3390/ app12031460

Academic Editor:

Alireza Dehghanisanij

Received: 23 December 2021

Accepted: 27 January 2022

Published: 29 January 2022

Publisher's Note: MDPI stays neutral with regard to jurisdictional claims in published maps and institutional affiliations.

Copyright: (C) 2022 by the authors. Licensee MDPI, Basel, Switzerland. This article is an open access article distributed under the terms and conditions of the Creative Commons Attribution (CC BY) license (https:// creativecommons.org/licenses/by/ $4.0 /)$

\begin{abstract}
Due to the depletion of traditional energy sources, the rising costs of their operation and the need to transition to a sustainable economy, it becomes relevant to increase the share of renewable energy sources in total consumption. The purpose of this study is to determine the role of renewable energy and the establishment of factors determining pro-environmental behavior. The data of the author's sociological survey of the population of the Arctic regions of Russia and methods of descriptive statistics were used, and regression analysis was carried out. The study shows the ecological and energy characteristics of the Arctic regions of Russia. The main advantages and possibilities of transition to renewable energy sources have been identified. A relationship has been established between the degree of involvement in pro-environmental behavior and knowledge about renewable energy, the perceived importance of environmental problems, age, income, education, amount of waste produced and current electricity costs. It is shown that the degree of involvement in pro-environmental behavior affects the willingness to pay more for renewable energy. A number of institutional measures to promote renewable energy, increase willingness to pay for renewable energy and spread pro-environmental behavior are proposed.
\end{abstract}

Keywords: ecological problems; energy system; renewable energy; energy transition; pro-environmental behavior; behavioral factors; willingness to pay; Arctic regions of Russia

\section{Introduction}

Rapid development of the global economy in the past century has brought along growing environmental risks in many parts of the planet. The global community responded to these risks with concerted efforts towards adopting international treaties (e.g., the Paris Climate Agreement and some others [1]) to prevent further degradation of the natural environment and work out the actions for transition to more environment friendly technology, particularly in the energy sector. Meanwhile, the environmental risks are especially pronounced in Northern Arctic and sub-Arctic regions, where natural ecosystems are highly susceptible to human impacts [2,3]. The greatest risks for Russia's Arctic ecosystems today are accidents at fuel and energy facilities [4]; use of dirty fuels (heavy oil, diesel fuel, etc.) in cargo transport and heating [5]; prevalence of extraction industries in the economy of Arctic regions [6]; and the obsolete energy systems [5]. The latter are highly centralized, and their infrastructure is growing outdated and is poorly developed in remote Arctic areas, which often suffer from power supply failures [7]. Another noteworthy factor is the poor development of standby and standalone energy generating sources in the said areas. Resolution of these issues is crucial for the vitality of local communities and normal operation of emergency services and social infrastructure in the Arctic [8]. At the same time, trying to handle these problems in the framework of the obsolete energy system and 
inefficient institutional procedures characteristic of the energy sector of the Russian Arctic would entail aggravation of pressure that is already high on local ecosystems. These risks grow even greater as economic activities in the Russian Arctic region are gaining pace, and a preferential economic regime is instated to attract more investments to industrial projects, including energy-related ones [9]. A key challenge in this situation is to tackle multiple local problems of Russia's Arctic energy systems arising from their instability and unsustainability by reforming them in line with modern agreements on transition to greener energy.

As demonstrated by the experience of countries with well-developed energy systems, the process of energy transition and greening of the economy should involve all key economic actors [10-12], but an increasingly important role in green innovations and promotion of green energy belongs to local communities, associations of green activists and households as end consumers of energy [13-16]. The significance of grassroots green initiatives is incontestable. They can take a wide range of forms-from public events and campaigns to personal pro-environmental routines and consumer preferences $[17,18]$. Our study is particularly topical in the absence of previous papers with an integrated approach to the questions of green practices, awareness of renewable energy matters and willingness to pay more for it among residents of Arctic regions of European Russia and considering local communities as a potential key actor in the economy's transition to sustainable energy and the reform of the region's energy systems. It is no secret that the special conditions in Arctic territories, such as the extreme natural environment, the highly polarized settlement system, high costs of operating machines, buildings and facilities and the vulnerability of northern ecosystems, shape the local lifestyles and the use of green practices by people. Meanwhile, this is the region exposed to exceptionally heavy anthropogenic pressure [19]. What is noteworthy is the study area-northern sub-Arctic territories with extremely sparse population require customized approaches to renewable energy transition policies and should, therefore, be studied specifically. These circumstances taken together have determined the choice of the study area-Arctic parts of Karelia and the Murmansk Region bounded by the EU in the west, by the White and Barents Seas in the east and north and by Russian territories in the south.

Earlier studies on the subject have shown that living conditions and the possibility to take decisions on how to arrange them have a notable effect on the green practices of households and attitudes of individuals. It was found, e.g., that the average household income in the residential sector has an important effect on consumers' intentions to use renewable energy [20]. Research shows that apart from living conditions, green practices are significantly influenced by consumer environmental concern [21] and awareness of the methods that help conserve the environment (namely, renewable energy) [22]. Certain effects on green practices and the tendency to use renewable energy are produced by age and gender [23,24]. Our study undertook to identify how gender, age, income, place of residence and knowledge about renewable energy matters correlated with individuals green practices, including the level of involvement. The methods of catching up with developed countries in the renewable energy sector, including the application of their relevant experience, were considered as a means of ensuring social and economic security. At the same time, studies of differences between countries regarding the transition to renewable energy in households reveal quite a few specific local factors influencing this process and hindering direct transfer of tools and policies effective in one country and region to another region [25]. This fact necessitates a specialized study of the drivers of energy transition in specific Arctic conditions. There is a number of academic publications that need to be mentioned in the context of the study of challenges for the development of renewable energy in the Arctic region in question and energy system reform. Kuznetsov and Konovalova emphasized the role of distributed power generation and RES in the dynamic regulation of energy system loading, management decentralization and unimpeded power interchange between entities in the electricity market [26]. A very common practice in remote Arctic areas is the use of diesel-powered installations, while their abandonment 
for greener power sources is hindered by the high financial and administrative costs of replacing existing infrastructure and generating facilities, considering the systemic impact on the level of costs $[5,27]$. The effect of the existing socio-technical regime on the energy transition process in the Russian Arctic is high inertia due to the connection to the oil and gas industry [28]. A study of consumer behaviors in the climatically similar country of Finland revealed a growing gap between citizens' pro-environmental motivation and the practices of energy consumption and energy saving [18]. The green practices of the residents of Artic and sub-Arctic regions of European Russia bordering EU countries, however, have remained unstudied. Research in these areas is a contribution to the dataset for comparisons between countries and for identifying key institutional, cultural and behavioral patterns behind the specific roles of end users in the transition to a greener economy and sustainable energy in different countries and regions. The region of the study is shown in Figure 1.

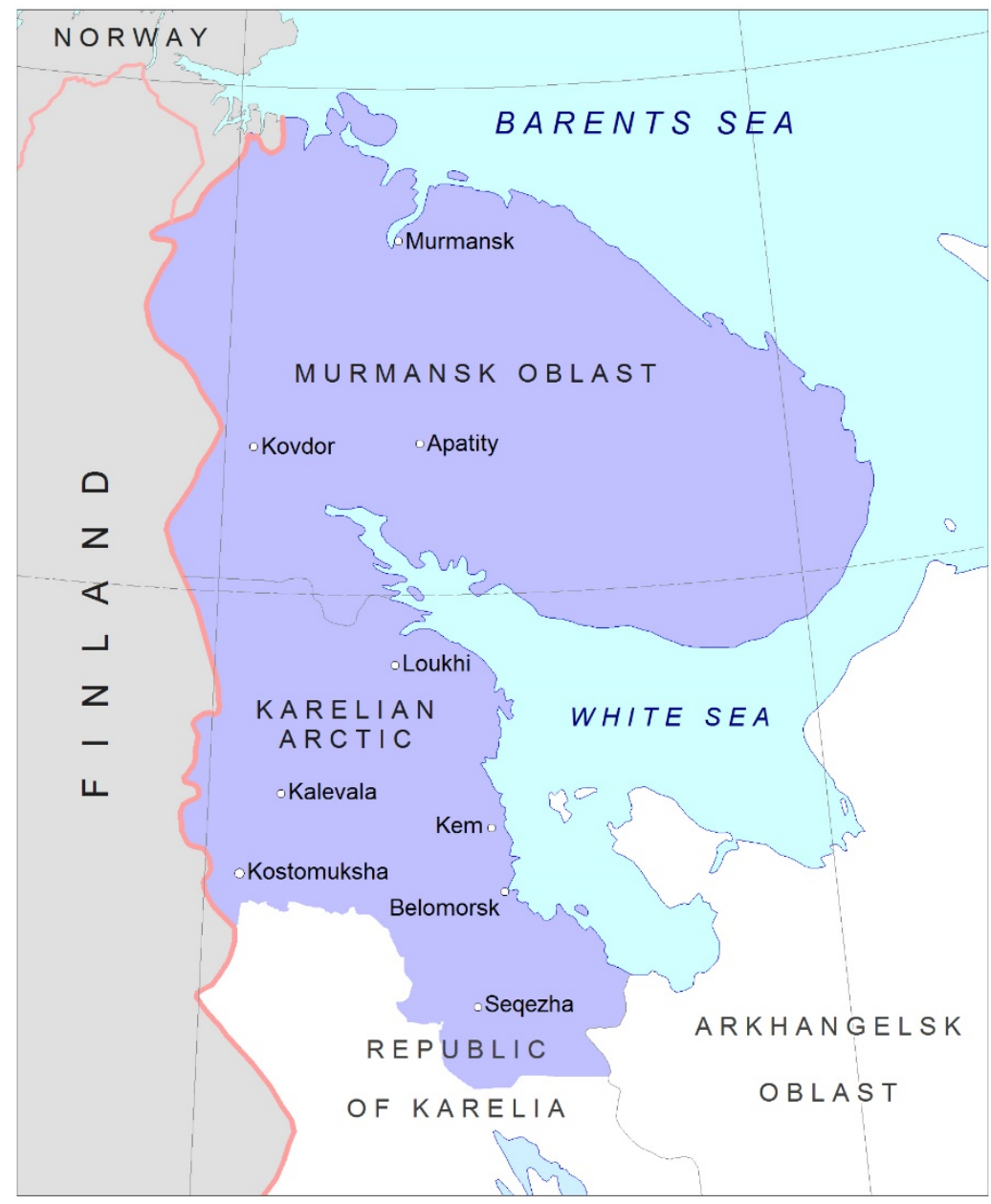

Figure 1. The region of the study.

The northern part of the presented region is characterized by an extremely polarized settlement system, and the southern part is more distributed. Settlements typical in their characteristics for the presented region were taken.

In the existing literature, the attitude towards the environment is usually understood as a judgment about the value of environmental protection. As part of the analysis, the attitude towards the environment was analyzed depending on the characteristics of the individual.

We checked two hypotheses. 
Hypothesis 1 (H1). Pro-environmental behavior positively depends on the age and income of the individual.

Hypothesis 2 (H2). Pro-environmental behavior characterizes individual waste generation and energy costs.

\section{Materials and Methods}

\subsection{Theoretical Framework}

The theoretical and methodological foundation of this study was the theories of the interaction of "society-nature" of the Chicago School of Sociology by W. Burgess, E. Park, L. Wirth and R. Mackenzie, R. [29-32]. In the studies of those scientists, the idea of ecological order as a factor in the development of society was first voiced. A change in the ecological order in the urban environment, according to representatives of the Chicago School (R. Park and E. Burgess), necessarily entails changes in people's habits, feelings and actions.

Environmental factors determine the need for adaptation and adaptation to environmental challenges, which are carried out in a variety of social practices theoretically presented in the works of P. Bourdieu and E. Giddens. Social practices are defined by P. Bourdieu as behavioral acts of social subjects that occur in accordance with their perceptions of the surrounding reality. P. Bourdieu considered social practices as expedient actions of individuals to transform the social world, as well as everyday routine not requiring explanation $[33,34]$. According to Giddens, social practices are understood as actions performed in a familiar fashion during everyday social activities. An important difference of this theory was the understanding of practices as routine social actions. In his opinion, "routine ensures the integrity of the personality of a social figure in the process of his daily activities, and is also an important component of the institutions of society, which are such only if they are continuously reproduced" [35].

The relationship between consciousness and behavior is justified in the value theory of P. Stern (Stern P.) [17,36-38]. He identified three types of environmental values: egoistic values (self-interest) - they are based on the belief about the harm of environmental risks to the health of environmental management subjects; altruistic values (altruism towards other humans), according to which the subject is involved in environmentally oriented actions to ensure a healthy environment for other subjects and future generations; andbiospheric values (altruism towards other species and the biosphere). The latter reflect the individual's belief in the absolute value of nature. Nature is recognized as inherently valuable, possessing the right to exist outside of the need to meet the needs of subjects [38]. Stern P. suggests two types of it: the first is environmental activism, which implies active participation in environmental organizations and demonstrations; the second is inactive behavior in the public sphere associated with the support of non-activists [36].

Stern P. and his colleagues [38] found empirical evidence that this type of influence can have a significant impact on public policy, the consequences of which can change the behavior of many people and organizations at the same time. Stern P. also identifies two types of environmental behavior of non-activists: intent-oriented behavior and impactoriented behavior, and both concepts are independent and do not define each other [38]. Environmental practices of the population in the field of reducing consumption waste, environmental consciousness and behavior as integral structural components were studied in the studies of concepts of environmental practices that are developed in the scientific research of D. Meadows [39], N. Reymers [40] and N. Moiseev [41].

\subsection{Methodology and Sampling Parameters}

This research used quantitative methods to collect data, including demographic data, and the SPSS statistical package was used to analyze the data.

Data were collected by using a mass questionnaire-based survey of residents in parts of the Murmansk Region and Karelian Arctic districts performed by the team of authors in the summer of 2020. The survey method was direct interviewing. Study area consisted 
of the following: 6 Arctic municipal districts of the Republic of Karelia and 3 cities of the Murmansk region. The survey was based on a stratified route sample with quota selection of survey units in the last step. The first step was segmentation by the level of socioeconomic development of the region. The second step was the selection of respondents based on gender and age quotas representative of the structure of the total population. The sample set included permanent residents of the stated areas aged 18-72 years. An average respondent was 41.7 years old. The survey covered 1505 respondents. The gender and age structure of the sample was similar to that of the total population, featuring the following percentages (Table 1).

Table 1. The ratio of sample parameters and characteristics of the population of the studied territories.

\begin{tabular}{ccc}
\hline & Region's Population (\%) & Sample Set (\%) \\
\hline $\begin{array}{c}\text { Gender (residents 18-72 years of age) } \\
\text { Male }\end{array}$ & 47.6 & 45.5 \\
\hline Female & 52.4 & 54.5 \\
\hline $\begin{array}{c}\text { Age cohorts } \\
18-29\end{array}$ & 15.7 & 20.7 \\
\hline $30-54$ & 54.7 & 59.1 \\
\hline $55-72$ & 29.6 & 20.2 \\
\hline
\end{tabular}

The available sample is similar to the general population. There is a slight shift in the gender and age profile towards female persons. In the age aspect, the sample parameters are somewhat shifted towards younger age categories.

The toolkit included blocks of questions to record contextual variables (age, gender, education and income); private sphere green practices (switch off the lights when leaving the room, try to combine the household needs of the family in order to save electricity and reduce the costs, etc.); non-activist public-sphere behaviors (support an NGO dealing with environmental or green energy issues financially; meet with representatives of energy companies, appeal to the authorities on green energy issues, etc.); and environmental activism (participate in nonviolent environmental activism, participate in an environmental NGO, etc.). A four-point (never; sometimes; often; and always) scale was used for most of the questions. The questionnaire used in this analysis is part of a larger questionnaire that also includes questions about the perception of current environmental problems, threats and their sources by the population.

The study examined the following statements about the implementation of eco-practices:

1. I am a member of environmental organizations.

2. I donate environmental organizations.

3. I report violations of environmental and environmental laws to the police.

4. I independently pursue the pollutants of nature.

5. I go out on weekend clean-up events, garbage collection in the common area, in the forest and other places.

6. I come up with environmental initiatives and appeals to authorities.

7. I initiate weekend clean-up events, garbage collection in the common area and in the forest.

8. I buy eco-labeled products.

9. I care about reducing energy consumption.

10. I choose natural products from local producers.

11. I choose more environmentally friendly ways of transportation (biking, walking, etc.).

12. I sort household waste for recycling.

13. I care about reducing the amount of water consumed.

14. I strive to reduce my consumption of disposable household items (such as plastic cups). 


\section{Results}

According to survey results, the most familiar and popular forms of energy among the respondents are solar energy, wind energy and hydropower (Table 2). At the same time, biomass energy took the smallest value. Meanwhile, this particular type of energy has historically been the most used type of renewable energy not only in the Arctic but also in the world as a whole [42]. Based on survey data, it can be assumed that this type of energy is already perceived by respondents as traditional energy. At the same time, assessing its economic potential, we came to the conclusion that the energy of biomass is underestimated by respondents.

Table 2. What types of renewable energy sources do you know?

\begin{tabular}{ccc}
\hline & Number of Responses & Number of Responses (Percentage) \\
\hline Wind energy & 867 & $24 \%$ \\
Solar energy & 1033 & $28 \%$ \\
Hydro power & 768 & $21 \%$ \\
Geothermal energy & 339 & $9 \%$ \\
Marine energy & 398 & $11 \%$ \\
Biomass energy & 233 & $6 \%$ \\
\hline
\end{tabular}

The bulk of the population was not involved or weakly involved in green practices (74\% in total; Table 3). The largest group was that with low involvement (49\%). Only $7 \%$ of respondents declared strong and extremely strong involvement in environmental practices.

Table 3. Degree of involvement in environmental practices.

\begin{tabular}{cc}
\hline Final Score (the Sum of Active and Passive Practices) & Interpretation \\
\hline 0 & not involved \\
$0.1-0.4$ & poorly involved \\
$0.5-0.9$ & moderately involved \\
$1.0-1.4$ & heavily involved \\
$1.5-2.5$ & extremely involved \\
\hline
\end{tabular}

The population poorly involved in green practices most often sought to reduce the consumption of disposable household items (48\%) and to reduce water consumption (35\%).

The population moderately involved in green practices most often sought to reduce the consumption of disposable household items (82\%), chose local organic products (69\%) and tried to reduce energy consumption $(63 \%)$.

The population strongly and extremely strongly involved in green practices most often cared for the environment by reducing the consumption of disposable household items (85\%), choosing local organic products (78\%), reducing the consumption of energy $(78 \%)$ and water $(70 \%)$ and choosing a more environmentally friendly type of transportation $(65 \%)$.

Thus, regardless of their involvement in pro-environmental practices, people tended to perform the following: reduce the use of disposable tableware (for example, plastic glasses) and use less water and energy.

The groups strongly and extremely strongly involved in green practices were as follows:

- $\quad$ Residents of Murmansk;

- Men;

- $\quad$ Aged 30 to 54;

- With higher education.

The group not involved in green practices had the following characteristics:

- Residents of Kovdor;

- Men; 
- $\quad$ Aged 30 to 54;

- With higher education.

The degree of involvement in green practices increases with the rise in material wellbeing (Figure 2).

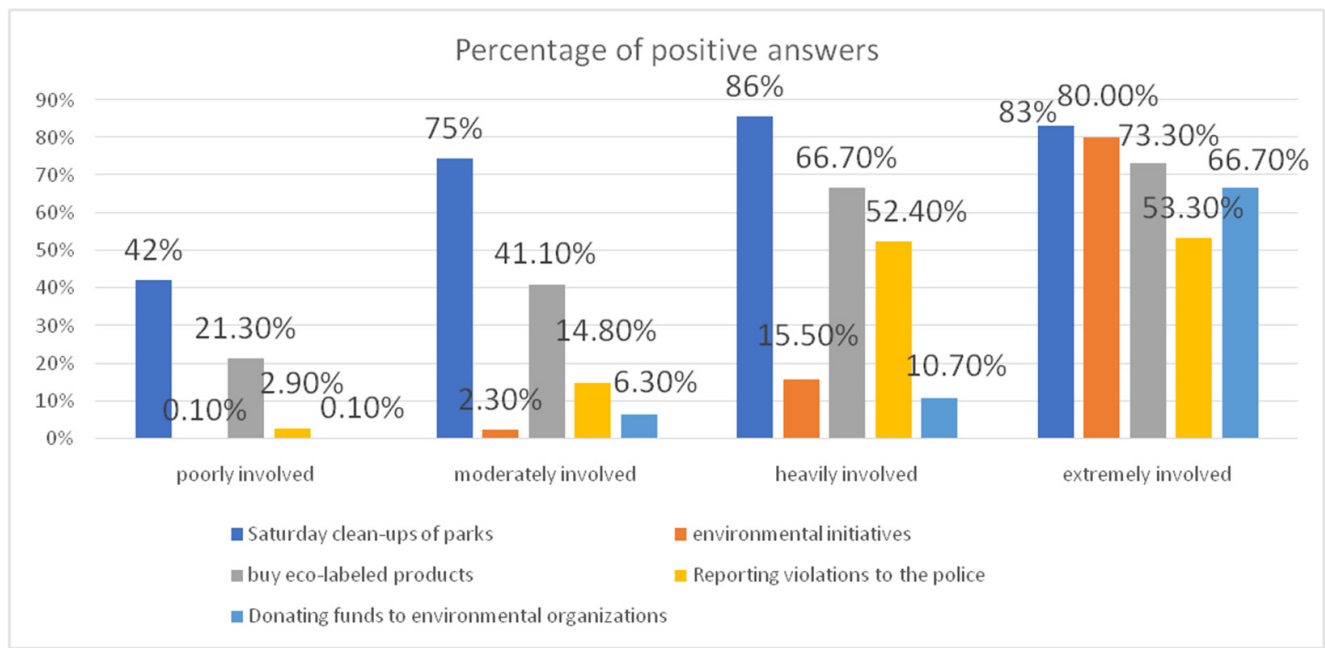

Figure 2. Pro-environmental behaviors of groups.

For residents with an extremely high degree of involvement in green practices, the most important problems are environmental problems (for example, air and water pollution, wastes and climate change; $100 \%$ of respondents) and economic problems (poverty and social inequality; $80 \%$ ).

The main global concerns for the population not involved in environmental practices were economic problems (65\%) and health problems such as cancer and cardiovascular and infectious diseases $(60 \%)$. However, more than half of them recognized existing environmental problems.

Groups with an extremely strong degree of involvement in green practices attached great importance to environmental issues. Of these, respondents highlighted air pollution and loss of biodiversity (average score 4.8 on a five-point scale in both cases) and water pollution (4.5 points) as the most significant.

Residents not involved in green practices found the following environmental problems to be important: air and water pollution (4.2 and 4.1, respectively); and household waste generation-4.0 points. The problem of global warming was recognized as the least significant in both groups of the population (Figure 3).

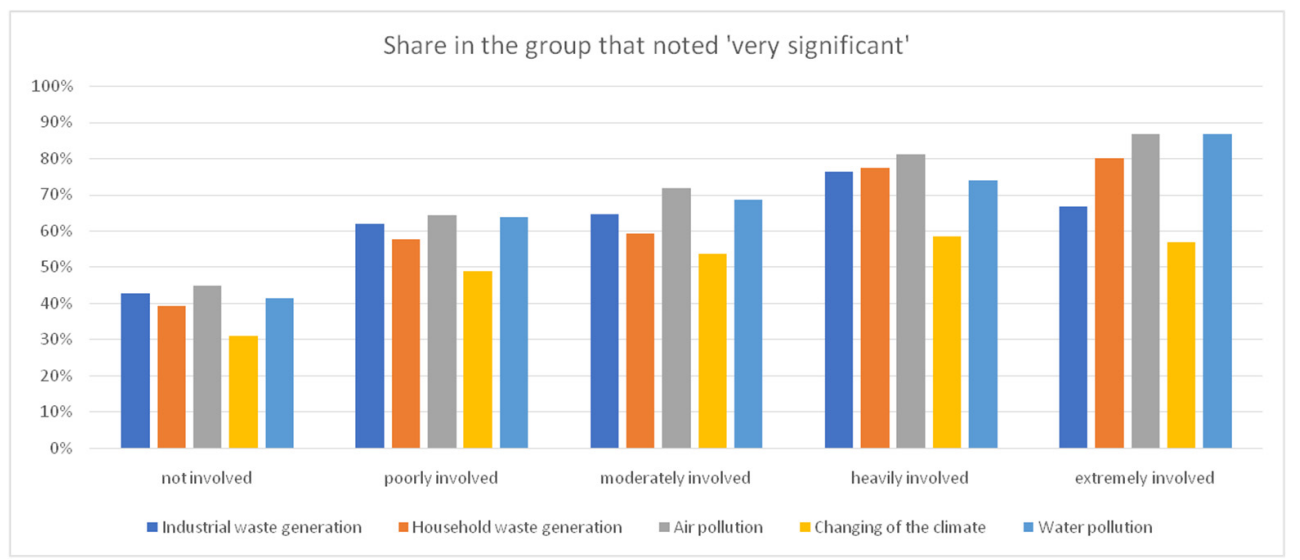

Figure 3. Attitude of respondents to environmental issues. 
Figure 4 shows the attitude to clean energy. The data show how people are willing to bear certain costs in the transition to sustainable development.

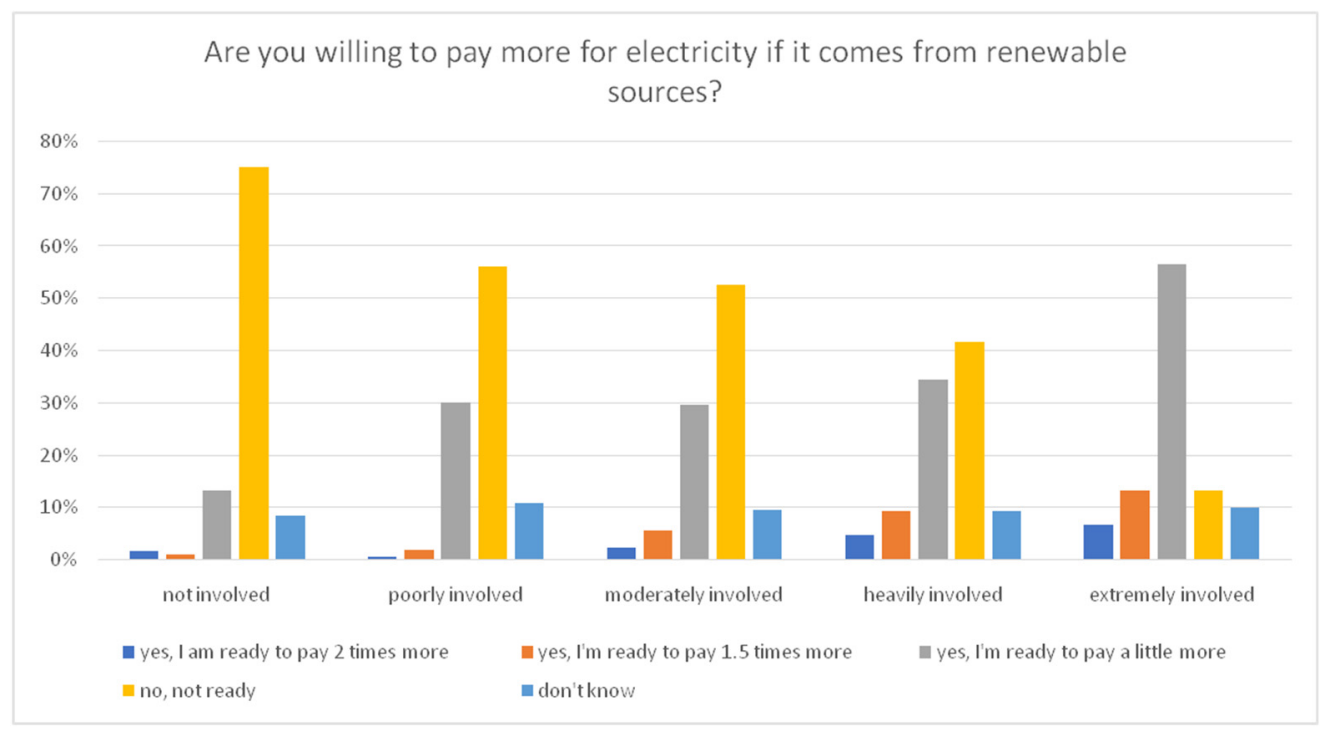

Figure 4. Attitude of respondents to renewable energy sources.

In order to analyze pro-environmental behavior based on survey data, we built a regression dependence of ecological behavior on the following factors.

Environmental behavior $=\mathrm{f}$ (respondent's age and education level, respondent's income, environmental parameters).

The environmental variables were the amount of waste generated by the family and the electricity costs per month.

Looking for correlations between variables, we started with the Granger causality test. This test is a necessary but constitutes an insufficient condition for causality.

By conducting the Granger causality test, we can analyze the causal relationships amongst environmental behavior, electricity costs, household income, (level of) education, waste generated and age. The results of the Granger test are presented in Table 4 . If $\mathrm{P}$ value is below 0.05 , the null hypothesis is rejected. It is clear from the data that direct causality of pro-environmental behaviors is detected for electricity costs and for household income for a lag of 2 (Table 4). Other variables show a two-way relationship, except for waste generated. Waste generated exhibits a causality for a lag of $3(p=0.02)$.

Table 4. Pairwise Granger causality tests.

\begin{tabular}{ccc}
\hline Null Hypothesis & F-Statistic & Prob. \\
\hline Electricity costs do not Granger Cause EB & 4.89160 & 0.0077 \\
Household income does not Granger Cause EB & 11.2698 & $1 \times 10^{-5}$ \\
Waste generated does not Granger Cause EB & 2.25490 & 0.1053 \\
AGE does not Granger Cause ECOLOG & 0.41438 & 0.6608 \\
Education does not Granger Cause EB & 0.62286 & 0.5366 \\
\hline
\end{tabular}

Let us now construct the linear relationship between our variables. Table 5 shows the results of the regression analysis. 
Table 5. Results of regression analysis.

\begin{tabular}{ccccc}
\hline & Coefficient & Standard Error & $t$ Statistic & $p$ Value \\
\hline C & 0.279 & 0.055 & 5.11 & 0.0000 \\
Age & 0.002 & 0.0008 & 2.64 & 0.0080 \\
Education & 0.016 & 0.008 & 1.98 & 0.0470 \\
Household & $1.52 \times 10^{-6}$ & $2.10 \times 10^{-7}$ & 7.233 & 0.000 \\
income & -0.00095 & 0.0005 & -1.89 & 0.059 \\
Waste generated & $-4.32 \times 10^{-5}$ & $1.23 \times 10^{-5}$ & -3.52 & 0.0004 \\
Electricity costs & & & & \\
\hline
\end{tabular}

The following equation was obtained.

Pro-environmental behavior $=0.279+0.002 *$ Age $+0.16 *$ edu $+0.00000152 *$ Household income $-0.00095 *$

Waste generated $-0.0000432 *$ Electricity costs

According to the results, age, level of education and income have a positive effect on pro-environmental behavior. Waste generated by the family and electricity costs per month are negatively related topro-environmental behavior. Thus, the population that is not involved in green practices generated more waste and did not practice energy saving.

Thus, we can argue that the first hypothesis about the positive dependence of proenvironmental behavior on income and age is confirmed. The second hypothesis is also confirmed, i.e., people who are not involved in green practices generate more waste and consume more energy. The chosen model is characterized by a low R Square value (0.07), and this may be due to the complex structure of pro-environmental behavior, which may further require more variables than collected in the survey, and to difficulties in collecting and quantifying factors.

We also tested the different forms of relationships between the variables' environmental behavior, electricity costs, household income, (level of) education, waste generated and age. Table 6 shows the Akaike information criterion (AIC) and Schwarz information criterion (also SIC), which enable comparisons between models with different numbers of parameters. The best model is indicated by the lowest value of the criterion. Importantly, model comparisons have to be based on samples of the same length. The table demonstrates that the linear model is optimal since the quadratic and cubic functions have the same values of AIC and BIC as the linear model (age was taken as the variable for the non-linear relationship hypothesis), while the logarithmic function is inferior to the linear function in these criteria.

Table 6. Results of regression analysis.

\begin{tabular}{ccc}
\hline Type of Model & Akaike info Criterion & Schwarz Criterion \\
\hline Linear & 0.78 & 0.81 \\
Quadraticfunction & 0.78 & 0.81 \\
Cubicfunction & 0.78 & 0.81 \\
Logarithmicfunction & 2.34 & 2.37 \\
\hline
\end{tabular}

\section{Discussion}

The aim was to identify variables that influenced pro-environmental behavior and the need to customize energy and environmental development programs for Arctic regions.

Previous studies have demonstrated a correlation to exist between awareness of renewable energy sources (RES) and pro-environmental behavior [22,43]. The results of our survey confirmed the following correlation: People in the study area had low awareness of RES and were little involved in pro-environmental activities. We also show that the degree of involvement in green practices depends on the level of environmental concern, which corroborates previous research results [14,44], and on the place of residence [45]. A direct relationship was found between the degree of involvement in green practices and 
the household's income (agrees with conclusions in [24]; as applied to RES, the relationship between the scope of their use and income is shown in $[20,22])$.

The positive dependence of pro-environmental behavior on age corroborates [46] and disproves [47]; the existence of statistically non-significant differences in age effect was demonstrated in [48]; and the lack of correlation was declared in [49]. The controversial conclusions regarding the effect of age and no individual's tendency to implement green practices may indicate that the direction of age effects vary among the practices. This is probably why the most and least pro-environmentally behaving individuals belong to the same age group of 30 to 54 years, although our survey has corroborated a positive correlation to exist between age and pro-environmental behavior.

Similarly, the survey has demonstrated that both the highest and the lowest involvements in green practices are exhibited by men and by persons with higher education (in the context of a general positive correlation between education and involvement in pro-environmental behavior). At the same time, a majority of studies report a greater involvement of women $[23,24,48,50,51]$ and persons with higher education $[24,48,49]$ in green practices, although men are said to be more sensitive to programs that attempt to change their behavior [52]. One can suppose that women on average are more willing to practice pro-environmental behaviors, but they spend more time at home [53] and more often demonstrate a moderate level of involvement in green practices. Men's motivation to behave pro-environmentally is lower on average, which is why their pro-environmental activity is the lowest. That said, there are also environmentally concerned men, who have more possibilities to implement green practices outside of home compared to women [53], and their involvement in the practices is, therefore, high rather than moderate.

The fact that people with higher education are among both the least and the most environmentally active individuals can be explained by differences in education itself. In the past, little attention was paid to environmental problems; thus, older people with higher education may stick to traditional, non-environmental behaviors. People recently out of university are more aware of environmental problems and more likely to behave pro-environmentally. The two-way relationship between education and pro-environmental behavior is evidence that the use of green practices has a positive effect on people's selfdevelopment aspirations, which is another benefit from environmental policies.

Early studies demonstrated a positive correlation between willingness to pay more for green electricity and energy-saving behavior [54] and a negative correlation between willingness to pay and regularity of segregating waste [47]. The analysis of green practices in their entirety in our study confirmed that individuals more involved in pro-environmental behavior are willing to pay more for electricity derived from RES. On the other hand, the results of the survey in general reveal low willingness of the respondents to bear high RES costs. The willingness to pay more for RES is shown to depend on the country's institutional arrangements. RESs are valued more in more democratic and capitalist countries and in countries with higher GDP per capita. High $\mathrm{CO}_{2}$ emissions in a country, on the other hand, reduce the willingness to pay for renewable energy [55]. We can thus assume that, as Russia's economic development advances and its $\mathrm{CO}_{2}$ emissions are reduced, people will be more willing to pay extra for green electricity.

That said, low willingness to pay extra is also observed in developed countries, e.g., in New Zealand, where consumers on average are willing to pay only an extra of $2 \%$ for a 10 percentage point increase in the share of electricity from renewable sources [56]. Considering the high cost of RES [57-59], such unwillingness to pay more is one of the key challenges for the development of green energy (it is one of the biggest factors for the unwillingness to transit to renewable sources [20]). Keeping in mind the correlation of willingness to pay extra with environmental awareness, environmental attitudes, peer support and income [47], as well as the negative effect of increasing social benefits on the development of the green energy market [43], the principal solutions for addressing this challenge are to raise environmental awareness, support the real sector of the economy to raise the income of industry workers and to technically upgrade the green energy 
production process. Knowing that the willingness to pay for renewable energy differs by source, it is reasonable, other factors being equal, to promote solar energy above biomass and farm methane [60] and hydropower [61].

In Russia, in 2017, the prices for wind and solar energy were, respectively, three and eight to nine times higher than the prices of thermal power plants and nuclear power plants [62]. Currently, in the world, the cost of producing electricity from renewable energy sources is decreasing, which, of course, is reflected in its price for end consumers [63]. One of the main reasons for this can be called the improvement of electricity production technologies [64]. What is particularly indicative is the reduction in capital costs of solar power generation [63]. Already in Russia, in a number of peripheral settlements, the use of renewable electricity is economically justified [65]. It is predicted that, in the near future in the world, on average, green energy may cost less than nuclear energy and energy from fossil sources [63]. However, in Russia, unlike in many other countries, this process will be hampered by the artificial maintenance of low prices for fossil fuels in the domestic market (these prices are lower than export prices and prices in developed foreign countries). In addition, it should be understood that the dynamics of average prices do not always correlate with the dynamics of prices in individual territories, since the price of the final consumer of electricity depends not only on the costs of its production, but also on the costs of transmission and natural and climatic features (insolation, etc.) [66].

The plan for future studies is to build relationships for the dependence of proenvironmental behavior on gender, age and education by taking into account the putative influence of age on the power and direction of the effect of education, and the two-way relationship between the use of green practices and the level of education.

\section{Conclusions}

This article demonstrates that the task of tackling energy and environmental problems is particularly topical in Arctic regions of Russia. For instance, some regions lack centralized power supply. At the same time, the density of economic activity is very low due to unevenly distributed population and the establishment of pivot zones at the government level. Considering these factors, it is expedient to develop small-scale power generation and renewable energy in these areas. This approach can secure steady power supply to users in Arctic regions, but it cannot be implemented without support from the local community and its willingness to change lifestyles accordingly.

A possible solution for environmental problems to begin with could be local initiatives for waste separation, weekend clean-up events and collaboration with international conservation organizations.

On the other hand, despite the good experience of the energy and environmental policies for promoting sustainable development in developed countries, previous studies show that policy transferability is limited: if successful practices are transferred without regard to the specific local features, the outcome of their implementation may be very different [67-69].

The high differentiations of the socio-economic conditions for the life of people across Russia and varying media coverage and awareness of energy and environmental problems generate differences between regions in the practices used by their citizens and willingness to alter their behavior to facilitate sustainable development. A conclusion from our survey is that residents of Arctic regions do not yet possess the knowledge and competencies necessary for the transition to a sustainable and environment friendly power supply system. Hence, for the energy policy to be effective, its implementation must be preceded by public environmental awareness building activities. Our results also demonstrate the need to support the real economy sector to increase incomes and create the conditions for production process renovation. The renewable energy sources that can be developed with higher economic effect due to people's willingness to pay more for them, all other things being equal, have been identified. 
Thus, the results of our study deepen the scientific understanding of the potential contained in the end users of energy and their green practices in the process of energy transition and reform of energy systems in the Russian Arctic, which are characterized by high developmental inertia. New findings include, in particular, the assertion of the need to take into account the readiness of the local community for the new energy and environmental policies; identification of the factors that shape citizens' pro-environmental behaviors and their specific effects; and outline of the methods for customizing successful practices in improving the energy and environmental safety of the regions.

In view of the above, this study is of practical significance. Knowing the factors for citizens' pro-environmental behavior authorities and NGOs can assemble an effective toolkit for stimulating sustainable behaviors of people in Arctic regions and for successful adaptation of the available environmental programs and policies to local realities. Implementation of an effective policy for motivating local communities together with collaboration between authorities, NGOs and citizens in dealing with energy and environmental problems can help reduce environmental deterioration in the area and lower energy and environmental threats.

Author Contributions: Conceptualization, S.T., A.T. and A.V.; methodology, S.T., A.T., V.K.-G., A.V. and A.S.; software, A.T.; formal analysis, A.T.; investigation, S.T., V.K.-G., A.V. and A.S.; resources, S.T.; data curation, S.T., V.K.-G., A.V. and A.S.; writing-original draft preparation, S.T., A.T., A.V. and V.K.-G.; writing-review and editing, S.T., A.T.,V.K.-G. and A.V.; visualization, A.T.; supervision, S.T.; project administration, S.T. All authors have read and agreed to the published version of the manuscript.

Funding: This research was funded through state assignment to the Karelian Research Centre RAS «Comprehensive research and development of the fundamentals of sustainable development management of the northern and border zones of Russia in global challenges».

Institutional Review Board Statement: Not applicable.

Informed Consent Statement: Informed consent was obtained from all subjects involved in the study.

Data Availability Statement: The data that support the findings of this study are available from thecorresponding author upon reasonable request.

Conflicts of Interest: The authors declare no conflict of interest.

\section{References}

1. Schleussner, C.-F.; Rogelj, J.; Schaeffer, M.; Lissner, T.; Licker, R.; Fischer, E.M.; Knutti, R.; Levermann, A.; Frieler, K.; Hare, W. Science and Policy Characteristics of the Paris Agreement Temperature Goal. Nat. Clim. Chang. 2016, 6, 827-835. [CrossRef]

2. Elias, S.A. Human Impacts on Arctic Ecosystems. In Encyclopedia of the World's Biomes; Goldstein, M.I., DellaSala, D.A., Eds.; Elsevier: Oxford, UK, 2020; pp. 409-420, ISBN 978-0-12-816097-8.

3. Tolvanen, A.; Eilu, P.; Juutinen, A.; Kangas, K.; Kivinen, M.; Markovaara-Koivisto, M.; Naskali, A.; Salokannel, V.J.; Tuulentie, S.; Similä, J. Mining in the Arctic Environment: A Review from Ecological, Socioeconomic and Legal Perspectives. J. Environ. Manag. 2019, 233, 832-844. [CrossRef] [PubMed]

4. Rajendran, S.; Sadooni, F.N.; Al-Kuwari, H.A.-S.; Oleg, A.; Govil, H.; Nasir, S.; Vethamony, P. Monitoring Oil Spill in Norilsk, Russia Using Satellite Data. Sci. Rep. 2021, 11, 3817. [CrossRef]

5. Berdin, V.K.; Kokorin, A.O.; Yulkin, G.M.; Yulkin, M.A. Renewable Energy Sources in Isolated Regions of the Russian Arctic; WWF: Gland, Switzerland, 2017.

6. Baklanov, P.Y.; Moshkov, A.V. Spatial differentiation of the structure of economics of the regions of the arctic zone of the Russian Federation. Èkon. Reg. 2015, 2015, 53-63. [CrossRef]

7. Biev, A.A. Current Trends and Problems in the Formation of Heat Supply Infrastructure in the Russian Arctic. IOP Conf. Ser. Earth Environ. Sci. 2020, 539, 012146. [CrossRef]

8. Potravnyi, I.M.; Yashalova, N.N.; Boroukhin, D.S.; Tolstoukhova, M.P. The Usage of Renewable Energy Sources in the Arctic: The Role of Public-Private Partnership. Econ. Soc. Chang. Facts Trends Forecast. 2020, 13, 144-159. [CrossRef]

9. Novikova, T.; Gulakova, O. Assessment of Major Arctic Development Projects: New Challenges-New Responses. Transp. Res. Procedia 2021, 57, 370-375. [CrossRef]

10. Lindberg, M.B.; Markard, J.; Andersen, A.D. Policies, Actors and Sustainability Transition Pathways: A Study of the EU's Energy Policy Mix. Res. Policy 2019, 48, 103668. [CrossRef] 
11. Geels, F.W.; Kern, F.; Fuchs, G.; Hinderer, N.; Kungl, G.; Mylan, J.; Neukirch, M.; Wassermann, S. The Enactment of Socio-Technical Transition Pathways: A Reformulated Typology and a Comparative Multi-Level Analysis of the German and UK Low-Carbon Electricity Transitions (1990-2014). Res. Policy 2016, 45, 896-913. [CrossRef]

12. Stirling, A. Transforming Power: Social Science and the Politics of Energy Choices. Energy Res. Soc. Sci. 2014, 1, 83-95. [CrossRef]

13. Seyfang, G.; Smith, A. Grassroots Innovations for Sustainable Development: Towards a New Research and Policy Agenda. Environ. Polit. 2007, 16, 584-603. [CrossRef]

14. Soeiro, S.; Ferreira Dias, M. Renewable Energy Community and the European Energy Market: Main Motivations. Heliyon 2020, 6, e04511. [CrossRef] [PubMed]

15. Di Silvestre, M.L.; Ippolito, M.G.; Sanseverino, E.R.; Sciumè, G.; Vasile, A. Energy Self-Consumers and Renewable Energy Communities in Italy: New Actors of the Electric Power Systems. Renew. Sustain. Energy Rev. 2021, 151, 111565. [CrossRef]

16. Rommel, J.; Sagebiel, J.; Müller, J.R. Quality Uncertainty and the Market for Renewable Energy: Evidence from German Consumers. Renew. Energy 2016, 94, 106-113. [CrossRef]

17. Stern, P.C. Information, Incentives, and Proenvironmental Consumer Behavior. J. Consum. Policy 1999, 22, 461-478. [CrossRef]

18. Vainio, A.; Pulkka, A.; Paloniemi, R.; Varho, V.; Tapio, P. Citizens' Sustainable, Future-Oriented Energy Behaviours in Energy Transition. J. Clean. Prod. 2020, 245, 118801. [CrossRef]

19. Makarova, I.; Mavrin, V.; Magdin, K.; Barinov, A. Reducing Black Carbon Emissions in the Arctic Territories. Transp. Res. Procedia 2021, 57, 356-362. [CrossRef]

20. Masrahi, A.; Wang, J.H.; Abudiyah, A.K. Factors Influencing Consumers' Behavioral Intentions to Use Renewable Energy in the United States Residential Sector. Energy Rep. 2021, 7, 7333-7344. [CrossRef]

21. Mohd Suki, N. Consumer Environmental Concern and Green Product Purchase in Malaysia: Structural Effects of Consumption Values. J. Clean. Prod. 2016, 132, 204-214. [CrossRef]

22. Vand, B.; Hast, A.; Bozorg, S.; Li, Z.; Syri, S.; Deng, S. Consumers' Attitudes to Support Green Energy: A Case Study in Shanghai. Energies 2019, 12, 2379. [CrossRef]

23. Irie, N.; Kawahara, N. Consumer Preferences for Local Renewable Electricity Production in Japan: A Choice Experiment. Renew. Energy 2022, 182, 1171-1181. [CrossRef]

24. Pinto, D.C.; Herter, M.; Rossi, P.; Borges, A. Going Green for Self or for Others? Gender and Identity Salience Effects on Sustainable Consumption. Int. J. Consum. Stud. 2014, 38, 540-549. [CrossRef]

25. Heiskanen, E.; Matschoss, K. Understanding the Uneven Diffusion of Building-Scale Renewable Energy Systems: A Review of Household, Local and Country Level Factors in Diverse European Countries. Renew. Sustain. Energy Rev. 2017, 75, 580-591. [CrossRef]

26. Kuznetsov, N.M.; Konovalova, O.E. Development of Distributed Energy in the Murmansk Region. Fundam. Res. 2021, 5, $122-127$. [CrossRef]

27. Pinto, H.; Gates, I.D. Why Is It so Difficult to Replace Diesel in Nunavut, Canada? Renew. Sustain. Energy Rev. 2022, 157, 112030. [CrossRef]

28. Morgunova, M. The Role of the Socio-Technical Regime in the Sustainable Energy Transition: A Case of the Eurasian Arctic. Extr Ind. Soc. 2021, 8, 100939. [CrossRef]

29. Park, R.E. On Social Control and Collective Behavior; The University of Chicago Press: Chicago, IL, USA; London, UK, 1967.

30. Burgess, E.W. ; American Sociological Association. The Urban Community: Selected Papers from the Proceedings of the American Sociological Society, 1925; University of Chicago Press: Chicago, IL, USA, 1926.

31. McKenzie, R.D. The Ecological Approach to the Study of the Human Community. Am. J. Sociol. 1924, 30, 287-301. [CrossRef]

32. Wirth, L. The Urban Society and Civilization. Am. J. Sociol. 1940, 45, 743-755. [CrossRef]

33. Bourdieu, P. Practical Reason Practical Meaning; Shmatko, N.A., Ed.; Shmatko, N.A., Translator; Alteia: St. Petersburg, Russia, 2001; ISBN 5-89329-351-7.

34. Bourdieu, P. Choses Dites; Shmatko, N.A., Ed.; Shmatko, N.A., Translator; Socio-Logos: St. Petersburg, Russia, 1994; ISBN 5-86942-006-7.

35. Giddens, A. Fate, Risk and Security. In The Sociology of Risk and Gambling Reader; Routledge: London, UK, 2006 ; pp. 37-67.

36. Stern, P.C. New Environmental Theories: Toward a Coherent Theory of Environmentally Significant Behavior. J. Soc. Issues 2000, 56, 407-424. [CrossRef]

37. Stern, P.C. Understanding Individual's Environmentally Significant Behavior. Environ. Law Rep. 2005, 35, 10785-10790.

38. Stern, P.C.; Dietz, T.; Abel, T.; Guagnano, G.A.; Kalof, L. A Value-Belief-Norm Theory of Support for Social Movements: The Case of Environmentalism. Res. Hum. Ecol. 1999, 6, 81-97.

39. Meadows, D.H.; Randers, J.; Meadows, D.L. Limits to Growth: The 30-Year Update, 3rd ed.; Chelsea Green Publishing: White River Junction, VT, USA, 2004; ISBN 978-1-931498-58-6.

40. Reymers, N.F. Conservation of Nature and the Environment. Reference Dictionary; Prosveshcheniye: Moscow, Russia, 1992.

41. Moiseev, N.N. Human, Environment, Society. Problems of Formalized Description; Nauka: Moscow, Russia, 1982.

42. Velkin, V.I. Methodology of Calculation of Complex RES Systems for Use on Autonomous Objects; UrFU: Ekaterinburg, Russia, 2015; ISBN 978-5-321-02460-7.

43. Ziaei, S.M. The Impacts of Household Social Benefits, Public Expenditure on Labour Markets, and Household Financial Assets on the Renewable Energy Sector. Renew. Energy 2022, 181, 51-58. [CrossRef] 
44. Rajapaksa, D.; Islam, M.; Managi, S. Pro-Environmental Behavior: The Role of Public Perception in Infrastructure and the Social Factors for Sustainable Development. Sustainability 2018, 10, 937. [CrossRef]

45. Pisano, I.; Lubell, M. Environmental Behavior in Cross-National Perspective: A Multilevel Analysis of 30 Countries. Environ. Behav. 2017, 49, 31-58. [CrossRef]

46. Raudsepp, M. Some Socio-Demographic and Socio-Psychological Predictors of Environmentalism. Trames J. Hum. Soc. Sci. 2001, $5,355-367$

47. Kowalska-Pyzalska, A. Do Consumers Want to Pay for Green Electricity? A Case Study from Poland. Sustainability 2019, 11, 1310 [CrossRef]

48. Kieżel, M.; Piotrowski, P.; Wiechoczek, J. Pro-Ecological Behaviours of Polish Consumers. Bus. Manag. Econ. 2019.

49. Dyr, W.; Prusik, M. Measurement of Proecological Attitudes Within New Ecological Paradigm in Polish Current Settings. Soc. Psychol. Bull. 2020, 15, 1-26. [CrossRef]

50. Liobikienè, G.; Grincevičienè, Š.; Bernatonienė, J. Environmentally Friendly Behaviour and Green Purchase in Austria and Lithuania. J. Clean. Prod. 2017, 142, 3789-3797. [CrossRef]

51. Xiao, C.; McCright, A. A Test of the Biographical Availability Argument for Gender Differences in Environmental Behaviors. Environ. Behav. 2014, 46, 241-263. [CrossRef]

52. Vicente-Molina, M.A.; Fernández-Sainz, A.; Izagirre-Olaizola, J. Does Gender Make a Difference in Pro-Environmental Behavior? The Case of the Basque Country University Students. J. Clean. Prod. 2018, 176, 89-98. [CrossRef]

53. Patel, J.; Modi, A.; Paul, J. Pro-Environmental Behavior and Socio-Demographic Factors in an Emerging Market. Asian J. Bus. Ethics 2017, 6, 189-214. [CrossRef]

54. Morera, F.; González, R.M.; Ramos-Real, F. Supplier Choice and WTP for Electricity Attributes in an Emerging Market: The Role of Perceived Past Experience, Environmental Concern and Energy Saving Behavior. Energy Econ. 2013, 40, 953-966. [CrossRef]

55. Chaikumbung, M. Institutions and Consumer Preferences for Renewable Energy: A Meta-Regression Analysis. Renew. Sustain. Energy Rev. 2021, 14. [CrossRef]

56. Ndebele, T. Assessing the Potential for Consumer-Driven Renewable Energy Development in Deregulated Electricity Markets Dominated by Renewables. Energy Policy 2020, 136. [CrossRef]

57. Du, E.; Zhang, N.; Hodge, B.-M.; Wang, Q.; Kang, C.; Kroposki, B.; Xia, Q. The Role of Concentrating Solar Power Toward High Renewable Energy Penetrated Power Systems. IEEE Trans. Power Syst. 2018, 33, 6630-6641. [CrossRef]

58. Arefin, S.; Mamoon, A.; Ping, H.W. Performance Investigation of an Advanced Hybrid Renewable Energy System in Indonesia: Environmental Progress \& Sustainable Energy. Environ. Prog. Sustain. Energy 2017, 37. [CrossRef]

59. Alagappan, L.; Orans, R.; Woo, C.K. What Drives Renewable Energy Development? Energy Policy 2011, 39, 5099-5104. [CrossRef]

60. Borchers, A.M.; Duke, J.M.; Parsons, G.R. Does Willingness to Pay for Green Energy Differ by Source? Energy Policy 2007, 35, 3327-3334. [CrossRef]

61. Sundt, S.; Rehdanz, K. Consumers' Willingness to Pay for Green Electricity: A Meta-Analysis of the Literature. Energy Econ. 2015, 51, 1-8. [CrossRef]

62. Letova, K.; Yao, R.; Davidson, M.; Afanasyeva, E. A Review of Electricity Markets and Reforms in Russia. Util. Policy 2018, 53, 84-93. [CrossRef]

63. Proskuryakova, L.N.; Ermolenko, G.V. The Future of Russia's Renewable Energy Sector: Trends, Scenarios and Policies. Renew. Energy 2019, 143, 1670-1686. [CrossRef]

64. Vasileva, E.; Viljainen, S.; Sulamaa, P.; Kuleshov, D. RES Support in Russia: Impact on Capacity and Electricity Market Prices Renew. Energy 2015, 76, 82-90. [CrossRef]

65. Lombardi, P.; Sokolnikova, T.; Suslov, K.; Voropai, N.; Styczynski, Z.A. Isolated Power System in Russia: A Chance for Renewable Energies? Renew. Energy 2016, 90, 532-541. [CrossRef]

66. Lanshina, T.A.; John, A.; Potashnikov, V.Y.; Barinova, V.A. The Slow Expansion of Renewable Energy in Russia: Competitiveness and Regulation Issues. Energy Policy 2018, 120, 600-609. [CrossRef]

67. Dolowitz, D.P.; Marsh, D. Learning from Abroad: The Role of Policy Transfer in Contemporary Policy-Making. Governance 2000, 13, 5-23. [CrossRef]

68. Peck, J.; Theodore, N. Fast Policy: Experimental Statecraft at the Thresholds of Neoliberalism. Minn. Scholarsh. Online 2015. [CrossRef]

69. Albrecht, M.; Yarovoy, G.; Karginova-Gubinova, V. Russia's Waste Policy and Rural Waste Management in the Karelian Republic: Building up a Ruin to Come? Fenn. Int. J. Geogr. 2020, 198, 135-150. [CrossRef] 